\title{
INVESTIGATION ON THERMAL-FLOW CHARACTERISTICS OF HTGR CORE USING THERMIX-KONVEK MODULE AND VSOP'94 CODE
}

\author{
Sudarmono \\ Center For Nuclear Reactor Technology and Safety \\ Kawasan Puspiptek Serpong, Tangerang 15310 Telp/Fax. 021-7560912 email: aksel@ batan.go.id \\ Diterima editor: 20 Januari 2015 \\ Direvisi editor: 18 Februari 2015 \\ Disetujui untuk publikasi: 23 Februari 2015
}

\begin{abstract}
INVESTIGATION ON THERMAL-FLOW CHARACTERISTICS OF HTGR CORE USING THERMIX-KONVEK MODULE AND VSOP'94 CODE. The failure of heat removal system of watercooled reactor such as PWR in Three Mile Islands and Fukushima Daiichi BWR makes nuclear society starting to consider the use of high temperature gas-cooled reactor (HTGR). Reactor Physics and Technology Division - Center for Nuclear Reactor Safety and Technology (PTRKN) has tasks to perform research and development on the conceptual design of cogeneration gas cooled reactor with medium power level of 200 MWt. HTGR is one of nuclear energy generation system, which has high energy efficiency, and has high and clean inherent safety level. The geometry and structure of the HTGR200 core are designed to produce the output of helium gas coolant temperature as high as $950{ }^{\circ} \mathrm{C}$ to be used for hydrogen production and other industrial processes in co-generative way. The output of very high temperature helium gas will cause thermal stress on the fuel pebble that threats the integrity of fission product confinement. Therefore, it is necessary to perform thermal-flow evaluation to determine the temperature distribution in the graphite and fuel pebble in the HTGR core. The evaluation was carried out by Thermix-Konvek module code that has been already integrated into VSOP'94 code. The HTGR core geometry was done using BIRGIT module code for 2-D model (RZ model) with 5 channels of pebble flow in active core in the radial direction. The evaluation results showed that the highest and lowest temperatures in the reactor core are $999.3{ }^{\circ} \mathrm{C}$ and $886.5{ }^{\circ} \mathrm{C}$, while the highest temperature of TRISO $\mathrm{UO}_{2}$ is $1510.20^{\circ} \mathrm{C}$ in the position $(\mathrm{z}=335.51 \mathrm{~cm} ; \mathrm{r}=0 \mathrm{~cm})$. The analysis done based on reactor condition of $120 \mathrm{~kg} / \mathrm{s}$ of coolant mass flow rate, $7 \mathrm{MPa}$ of pressure and $200 \mathrm{MW}_{\text {th }}$ of power. Compared to the temperature distribution resulted between VSOP'94 code and fuel temperature limitation as high as $1600{ }^{\circ} \mathrm{C}$, there is enough safety margin from melting or disintegrating.
\end{abstract}

Keywords: Thermal-Flow, VSOP'94, Thermix-Konvek, HTGR, temperature

\begin{abstract}
ABSTRAK
INVESTIGASI KARAKTERISTIK ALIRAN TERMAL TERAS HTGR MENGGUNAKAN THERMIXKONVEK MODULE AND VSOP'94 CODE. Kegagalan sistem pembuangan panas pada reaktor berpendingin air jenis PWR, Three Mile Islands dan reaktor BWR Fukushima Daiichi, menyebabkan masyarakat nuklir mulai memikirkan penggunaan reaktor pembangkit daya jenis temperatur tinggi berpendingin gas (HTGR). Bidang Fisika dan Teknologi Reaktor di Pusat Teknologi Reaktor dan Keselamatan Nuklir (PTRKN) mempunyai tugas melaksanakan kegiatan litbang desain konseptual reaktor kogenerasi dengan tingkat daya menengah yang berpendingin gas helium dengan daya 200 MWt. Desain HTGR200K merupakan salah satu sistem pembangkit energi yang memiliki efisiensi energi paling besar, dan tingkat keselamatan inheren yang tinggi dan bersih. Komposisi geometri dan struktur teras didesain agar dapat menghasilkan keluaran pendingin gas helium bertemperatur $950{ }^{\circ} \mathrm{C}$ sehingga dapat digunakan untuk produksi hidrogen dan atau unit industri proses lainnya secara kogeneratif. Luaran gas helium bertemperatur sangat tinggi ini akan menimbulkan tegangan termal pada bola bahan bakar yang mengancam integritas sistem pengungkungan produk fisi di dalamnya. Oleh karena itu perlu dilakukan evaluasi karakteristika termal flow untuk menentukan distribusi temperatur bahan bakar bola dan outlet temperatur pendingin gas helium teras HTGR. Hal ini dilakukan dengan menggunakan modul ThermixKonvek yang terintegrasi dalam program VSOP'94. Geometri teras HTGR dikerjakan dalam modul BIRGIT untuk model teras 2-D (R-Z) dengan 5 kanal aliran pebble dalam teras aktif arah radial. Hasil evaluasi menunjukkan bahwa nilai tertinggi dan terendah temperatur yang terdapat pada teras adalah sebesar 999.3 ${ }^{\circ} \mathrm{C}$ dan 886,5 ${ }^{\circ} \mathrm{C}$. Demikian pula hasil temperatur tertinggi bahan bakar TRISO dan bahan bakar pebble di dalam teras, yaitu diperoleh sebesar $1510,20^{\circ} \mathrm{C}$ yang terletak pada lapisan bahan bakar inti $\mathrm{UO}_{2}$, di posisi $z=335.51 \mathrm{~cm}$ dan $r=0 \mathrm{~cm}$. Analysis di lakukan pada laju massa aliran pendingin, tekanan dan daya masingmasing sebesar $120 \mathrm{~kg} / \mathrm{s}, 7 \mathrm{Mpa}$ dan 200MW $\mathrm{W}_{\text {th. }}$. Hasil perhitungan, jika dibandingkan dengan lisensi pembatas keselamatan terhadap maksimum temperatur bahan bakar pebble menunjukkan bahwa integritas bahan bakar pebble masih aman karena masih lebih rendah dari batas desain yaitu sebesar $1600{ }^{\circ} \mathrm{C}$.
\end{abstract}

Kata kunci: Thermal-Flow, VSOP'94, Thermix-Konvek, HTGR, temperatur 


\section{INTRODUCTION}

Some countries such as South Africa, China, Japan, and South Korea have successfully high temperature gas-cooled reactor (HTGR) designed. Depending on the reactor power, the core size and geometry are very specific and varied for each respective country. The failure of heat removal system of a water-cooled reactor PWR in Three Mile Islands and Fukushima Daiichi BWR made nuclear society consider the use of HTGR for power generation. Therefore, Indonesia has to carry out itself a conceptual design of HTGR core with local technical specification. Furthermore, other developed countries' experience in designing reactor core can be used as a reference and guidance in this research and development.

To design national nuclear reactor specific to Indonesia, core design has to follow the recommendations given by the International Atomic Energy Agency (IAEA) and consider the experiences of other countries that have designed similar reactor. The candidate HTGR design is an extension of the earlier designs of the Gas Turbine-Modular High Temperature Reactor (GT-MHR) and the Pebble Bed Modular Reactor (PBMR). The HTGR differs from these designs mainly in that the target reactor outlet temperature will probably be higher, although a specific target has not been defined. Moreover, the HTGR is to produce hydrogen in addition to electricity. The two reactor system designs differ mainly in the core configuration, which is, prismatic or pebble form for the reactor fuel.

Many HTGR assessments have been done by researchers. To overcome high absorption problem in neutron diffusion calculation, Reitsma et al. evaluated the use of control rod and ASTRA's criticality facility in their experiment and compared the results with VSOP code calculation results [1]. Meanwhile, Pilehvar et al. studied the main parameter characteristics of core thermohydraulics with compressible flow in the pebble bed modular reactor (PBMR) core. The analysis was carried out through porous medium using ANSYS CFX Code. Compared to the results of the other codes, the results of the analysis using ANSYS CFX code give very slight deviation [2].

One of the advantages of HTGR is the use of passive safety system. Ortensii et al. studied the HTGR passive safety system advantages, i.e. Doppler feedback effect, which is the best spatial and temporal representation of the feedback effect obtained from an accurate approximation of the fuel temperature [3]. The analysis used TRISO fuel temperature model, called THETRIS and coupled with CYNOD-THERMIX-KONVEK. These computer codes were also used to compute gas pressure at transient condition as a function of fast transient prediction [3]. The process of heat transfer in pebble reactor between fuel pebble and coolant flow attracted many researchers to study. Heat transfer phenomenon in pebble bed reactor was studied through experiment by Xianke et al. [4].

The experiment was performed in porous medium containing steel and carbon steel pebble with water as coolant. By the experiment and analysis, dimensionless average heat transfer coefficient criteria. It was also found that the deviation between the fitted results and the experimental results was $12 \%$ or less [4]. Paredes et al. studied the heat transfer process between TRISO particles and graphite. The averaging volume method (AVM) was used for the homogenization of the fuel pebble, which was an essential factor in equilibrium thermodynamic effect. The results showed that the non-equilibrium thermodynamic effects are relatively important, and that the two-equation model presents a greatest heat transfer resistance compared to the one-equation model [5].

Antwerpen et al. used a new approach to calculate thermal conductivity in the packed pebble bed reactors, called Multi-sphere Unit Cell model. This model was made specifically for computing porous structure, which was characterised using the radial variation in porosity, coordination number and contact angles between adjacent spheres, until $1200{ }^{\circ} \mathrm{C}$. The results show that this approach, which was used to characterize the porous structure, improved prediction of the effective thermal conductivity in the near-wall and wall regions, resulting in better prediction of the temperatures at the reflector interface [6]. Meanwhile, identification of heat flow and transfer of the pebble bed modular reactor necessitates a heat transfer model that deals with radiation as well as thermal convection and conduction.

Yamoah et al. carried out a modelling simulation. This simulation was done by developing a model that could simulate fluid flow and heat transfer in the pebble bed modular reactor. The results indicated that uniform pressure in the radial direction for a core to fuel element diameter (D/d) ratio > 20 and the heat transfer coefficient increases with increasing temperature and coolant mass flow rate 
[7]. Zheng et al. conducted a research to study Chinese HTR-PM $200 \mathrm{MW}$ reactor characteristics at asymmetric condition [8]. The analysis was done by comparing thermal hydraulic 2-D THERMIX calculation results with the results of 3-D ATTICA3D (Advanced Thermal hydraulics Tool for Invessel \& Core Analysis in 3D) reactor system analysis calculation. ATTICA3D code was used to compute reactor condition at steady state and transient condition during DLOCA (Depressurized Loss Of Coolant Accident).

The results show that based on symmetric cylindrical power distribution, the two codes give pressure drop and temperature distribution show in good agreement. At asymmetrical condition, in which one set of small absorber spheres (SAS) drops into the side reflectors resulting in an asymmetric distribution of the nuclear power, a three-dimensional calculation for the steady state is implemented to basically show the good 3-D simulation capabilities of ATTICA3D, which will be helpful to the next refined design stage for the HTR-PM project [8]. Nowadays. the deployment of high temperature gascooled reactor (HTGR) is being considered all over the world because of its excellent safety features. A particular inherent safety advantage of HTR designs is related to the very high temperature that the fuel can sustain basically preventing the fuel from melting even in the event of loss of cooling.

BATAN has performed an assessment of this reactor type by calculation analysis on its nuclear island safety aspect and auxiliary system [9]. The $200 \mathrm{MW}_{\text {th }}$ HTGR assessed to meet the User Criteria Document is then called HTGR. The thermal energy of the high temperature gas-cooled reactor system is supplied by the fuel pebble of the reactor core with $200 \mathrm{MW}_{\text {th }}$ thermal power. In accordance with the UCD developed, the high temperature gas-cooled reactor selected is a pebble bed reactor type with $\mathrm{UO}_{2}$ fuel in form of TRISO composing fuel pebble. The reactor safety is limited by the fuel temperature in the reactor core. To prevent the fuel integration from melting or disintegrating, the fuel temperature should be less than $1600^{\circ} \mathrm{C}$ [8].

Investigation on thermal-flow characteristics of HTGR core should have been done in the preliminary design. This design was carried out using THERMIX-KONVEK Module. This module has been already integrated into VSOP'94 code and the investigation is based on input data of modeling of the TRISO fuel coated, fuel pebble and core [10]. In addition, the reactor parameters, core and fuel pebble specification have been obtained.

The main objective of this study is to characterize the temperature distribution in the solid of each fuel layer, helium gas and pressure drop of HTGR core so that fuel pebble integrity and its cogeneration can be figured out in accordance with the UCD developed.

In the previous researches, a calculation analysis on solid material temperature distribution both inside and outside the HTGR core had been carried out to produce $200 \mathrm{MWth}$, in which the operation condition used was relatively, i.e. inlet temperature of $250{ }^{\circ} \mathrm{C}$ and pressure of 5 bar [11]. Meanwhile, in this research, the calculation performed is used for HTGR cogeneration purposes as to produce hydrogen gas by using helium gas temperature at over $950^{\circ} \mathrm{C}$ [9]. This case requires further investigation on thermal flow because high coolant temperature may cause extreme TRISO fuel characteristic changes, compared to the previous researches. Therefore, an investigation on TRISO fuel temperature distribution as a function of position in the reactor core as well as safety margin to maintain fuel integrity is necessary. Moreover, the temperatures resulted in this investigation are compared with those of the previous research and with the maximum safety margin of fuel pebble temperature, i.e. $1600^{\circ} \mathrm{C}$ [8]. This figure is chosen as a limit so that fuel pebble integrity is maintained and no radionuclide, such as Cs-137 causing hazard to human body, is released.

\section{CONCEPTUAL DESIGN OF HTGR REACTOR CORE}

High temperature gas-cooled reactor HTGR is a reactor that is being developed by BATAN in a conceptual design with capacity of $200 \mathrm{MW}_{\text {th }}$ [12]. This reactor will be used for power generation and industrial heat production. HTGR is a graphite-moderated and helium-cooled reactor. To convert heat generated by nuclear fission into electricity, direct and indirect Brayton gas cycles are used Helium coolant transfers the heat generated by fission reaction in the core from the primary system into steam generator. 
The heat is then used for various applications based on its temperature. This process is called cogeneration. In the steam generator, the heat is absorbed by feed water in the secondary system and the heat produced is transferred to a turbine. Fission process in the core is able to heat up the helium gas to $950^{\circ} \mathrm{C}$ with its thermal efficiency as high as $40 \%$ [12]. After heat exchange occurs in the secondary system, the helium temperature decreases to $650{ }^{\circ} \mathrm{C}$ and the helium gas is pumped back into the reactor core. The reactor core is located at the internal cavity, which consists of a cylindrical body at the top and cone region at the bottom.

HTGR core utilizing spherical fuel elements with ceramic coated fuel particle, is surrounded by graphite reflectors. HTGR core vertical cross-section is shown in Fig. 1 [13].

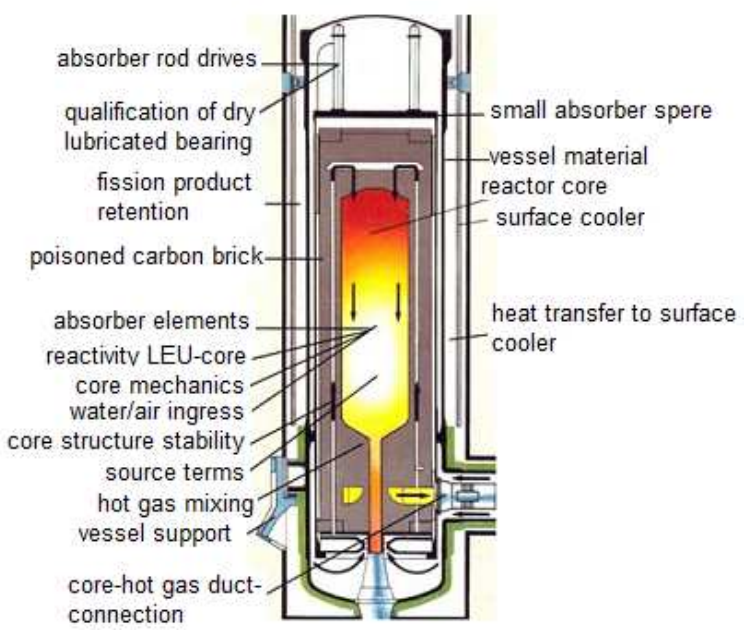

Figure 1. HTGR core vertical cross-section [13]

The average power density of the core is $3.22 \mathrm{MW} / \mathrm{m}^{3}$, located in the reactor pressure vessel (RPV) packed bed with $9.43 \mathrm{~m}$ high and diameter of $3 \mathrm{~m}$. The core contains about 359.548 spherical fuel pebbles in equilibrium. HTGR parameters and core specifications are shown in Table 1 [11]. Each pebble has diameter of $6 \mathrm{~cm}$ and contains about 5.394 fuel particle coated with "TRISO" of $0.92 \mathrm{~mm}$ in diameter dispersed in graphite matrix and the outer shell of $1 \mathrm{~cm}$ thick as free fuel zone. The dimension of fuel pebble for HTGR core is an active sphere with $5 \mathrm{~cm}$ in diameter containing thousands of TRISO-coated $\mathrm{UO}_{2}$ kernel in graphite matrix to form active spherical fuel pebble.

The fuel pebble and TRISO is coated at outer layer with $0.5 \mathrm{~cm}$-graphite shell (density 1.75 $\mathrm{gr} / \mathrm{cm}^{3}$ ) to form fuel pebble with $6 \mathrm{~cm}$ in diameter. TRISO-coated $\mathrm{UO}_{2}$ kernel has $0.092 \mathrm{~cm}$ in diameter. The enrichment of each pebble is $7 \mathrm{~g}$. The simulation testing of an accident carried out in Germany shows that TRISO-related pressure vessel failure will be observed during the heating test at $1600^{\circ} \mathrm{C}$ [8]. The fuel pebble containing TRISO particles can effectively confine all radioactive fission products until $1600^{\circ} \mathrm{C}$ [8]. This temperature has been set as the temperature boundary of the pebble in accident condition.

In the side reflector near the reactor core, eight control rods are installed for the reactivity adjustment and as the first shut down system, which allows the reactor to reach safe shutdown state, while 22 units of small absorber sphere (SAS) shutdown unit are designed as the second shutdown system to reach cold shutdown state. In addition, there are 30 gas channels located in the outer side reflector for the helium flow channels. The fuel loading tube with diameter of $6.5 \mathrm{~cm}$ is located at the top of the reactor core, while the fuel discharge tube is set at the bottom of the reactor core.

Table 1. HTGR parameters and core specifications [14]

Reactor parameters:
Thermal power $(\mathrm{MWth})$
Core volume $\left(\mathrm{m}^{3}\right)$
Core inlet temperature $\left({ }^{\circ} \mathrm{C}\right)$
Core outlet temperature $\left({ }^{\circ} \mathrm{C}\right)$
Pressure He $(\mathrm{MPa})$

Value
200
66,657
650
950
7




\begin{tabular}{|l|l|}
\hline \hline Reactor parameters: & Value \\
Mass flow rate $(\mathrm{kg} / \mathrm{s})$ & 120 \\
\hline Core specifications: & \\
Core height $(\mathrm{m})$ & 9,43 \\
Core diameter $(\mathrm{m})$ & 3.0 \\
Number of pebbles per $\mathrm{m}^{3}$ & 5.394 \\
Number of pebbles in the core & 359.548 \\
Volumetric filling fraction of balls in & \\
core (f) [\%] & 61 \\
\hline
\end{tabular}

The metallic internal part consists of core barrel, bottom supporting structure and top thermal shield, which supports the whole ceramic structure of the pebble-bed core. The dimension of fuel pebble for HTGR core is an active sphere with $5 \mathrm{~cm}$ in diameter containing thousands of TRISOcoated $\mathrm{UO}_{2}$ kernel in graphite matrix to form active spherical fuel pebble. This spherical fuel pebble is coated at outer layer with $0.5 \mathrm{~cm}$-graphite shell (density $1.75 \mathrm{gr} / \mathrm{cm}^{3}$ ) to form fuel pebble with $6 \mathrm{~cm}$ in diameter. TRISO-coated $\mathrm{UO}_{2}$ kernel has $0.092 \mathrm{~cm}$ in diameter.

\section{THERMAL-FLOW CHARACTERISTICS OF CALCULATION}

This research employs VSOP'94 code for calculation. VSOP'94 code was initially run in a mainframe computer of DEC-ALPHA Workstation with operating system of VAX/VMS [10]. To run VSOP'94 code, there are some conversion modules that should be prepared, such as CONGAM code. The CONGAM code is converting library's data into binary code for GAM.LIB. CONTHERMA module to convert library data of TERMOS into binary code, and ZUT-DGL module for integral calculation isotope resonance.

These modules should be provided first before they are used in DATA2, BIRGIT, and VSOPCITATION modules. VSOP'94 code utilizes two library's data, which are ENDF/B-IV and JEF-1. The GAM code performs epithermal spectrum calculation for nuklide compositions resulting from a homogenization of the respective regions. Self shielding factors can be applied for the many nuclides. They can be given in coarse energy groups or in the 68 group structure of the GAM-1 Library.

The GAM-1 library consist of 68 energy structural groups whose energy ranges from $10 \mathrm{MeV}$ to $0.414 \mathrm{eV}$, while THERMOS library data consist of 30 energy groups from $10^{-5} \mathrm{eV}$ to $2.05 \mathrm{eV}$. VSOP'94 data input use a "formatted input" type so that it is vulnerable to typing error. Therefore, VSOP-Utility really helps to prepare and build program input for VSOP'94. VSOP'94 modules used in the investigation are THERMIX-KONVEK. The THERMIX-KONVEK Module has been developed for thermal hydraulics investigation of the pebble bed HTGR in two dimensions.

The code calculates the temperature and flow conditions for steady state condition of the reactor. At a given time step, it receives the power distribution of the reactor from the nuclear code modules. It returns the corresponding temperatures of the fuel and moderator averaged over the volumes of the reactor spectrum zones, being ready for further neutronic investigation. The calculation of the overall heat transfer is synthesized of the coupling of different physical equations, which represent conservation laws. The equations are solved individually and the synthesis is made by a superposed iteration [10].

\section{CALCULATION METHOD}

In the analysis using THERMIX-KONVEK code, some data for modeling, calculation, observation reference points, simulation, and calculation results analysis are required. The modeling of TRISO fuel, fuel pebble, and HTGR core geometry is carried out.

1. TRISO and fuel pebble modeling parameters are shown in Table 2. TRISO fuel consists of Low Enriched Uranium-Triple Coated Isotropic (LEU-TRISO) with diameter of $0.092 \mathrm{~cm}$ and contains $\mathrm{UO}_{2}$ kernel with density of $10.4 \mathrm{gram} / \mathrm{cm}^{3}$ and enrichment of $10 \%\left({ }^{235} \mathrm{U}\right)$ coated by 
buffers, i.e. inner pyrolytic carbon (IPyC), silica carbide (SiC), and outer pyrolytic carbon $(\mathrm{OPyC})$.

Table 2. TRISO Fuel and Fuel Pebble geometry Modelling Parameters [14]

\begin{tabular}{|c|c|c|c|}
\hline No & Geometry/Material Type & & Values \\
\hline 1. & Kernel material & $=$ & $\left({ }^{235} \mathrm{U} /{ }^{238} \mathrm{U}\right)$ \\
\hline 2. & $\mathrm{UO}_{2}$ density $\left[\mathrm{g} / \mathrm{cm}^{3}\right]$ & $=$ & 10.40 \\
\hline 3. & Radius of fuel kernel $[\mathrm{cm}]$ & $=$ & 0.025 \\
\hline 4. & Material coating thickness starting from inside $[\mu \mathrm{m}]$ & $=$ & $90 / 40 / 35 / 35$ \\
\hline 5. & Coated particles density $\left[\mathrm{g} / \mathrm{cm}^{3}\right]$ & $=$ & $0.9 / 1.85 / 3.2 / 1.85 \mathrm{~g} / \mathrm{cc}$ \\
\hline 6. & Fuel matrix material & $=$ & graphite \\
\hline 7. & Coating layer material [starting from kernel] & $=$ & Buffer/IpyC/SiC/OPyC \\
\hline 9. & Diameter of ball $[\mathrm{cm}]$ & $=$ & 6.0 \\
\hline 10. & Diameter of fuelled zone $[\mathrm{cm}]$ & $=$ & 5.0 \\
\hline 11. & Density of graphite in fuelled zone $\left[\mathrm{g} / \mathrm{cm}^{3}\right]$ & $=$ & 1.73 \\
\hline 12. & Heavy metal (uranium) loading per ball [g] & $=$ & 5.0 \\
\hline 13. & Natural boron impurities in uranium [ppm] & $=$ & 4 \\
\hline 14 & Enrichment of ${ }^{235} \mathrm{U}$ & $=$ & $10 \%$ \\
\hline 15 & Shell graphite thickness $[\mathrm{cm}]$ & $=$ & 0.5 \\
\hline 16 & Shell graphite density $\left[\mathrm{g} / \mathrm{cm}^{3}\right]$ & $=$ & 1.75 \\
\hline 17 & Fuel loading, $\mathrm{g} /$ sphere $[\mathrm{mm}]$ & $=$ & 6.15 \\
\hline
\end{tabular}

Fuel pebble modeling contains active fuel with diameter of $5 \mathrm{~cm}$. This fuel pebble contains active kernel coated by $\mathrm{UO}_{2}$ TRISO dispersed in graphite matrix in a spherical shape, which is coated again by a $0.5 \mathrm{~cm}$ outer shell, to form a spherical fuel pebble with diameter of $6 \mathrm{~cm}$.

2. The core structural and material geometry of HTGR is shown in Figure 1. The reference node $0 \mathrm{~cm}$ is located at boundary of dummy pebble and fuel pebble. The most upper node is the cavity area with the upper boundary $1248 \mathrm{~cm}$ and the lowest node is $-445 \mathrm{~cm}$. The inlet is the upper part core, starting from cavity zone, before the entry of reactor core zone (node $943 \mathrm{~cm}$ ). Meanwhile, the outlet is located at lower part. The radial zone is divided into 15 nodes and the axial direction is divided into 8 nodes under node 0 (conus) and 24 nodes above node 0 . Core analysis with different power level and with different coolant flow rate is carried out. At each zone, fuel zone and coolant zone can be radially represented, while power density is represented axially. The cone for spent fuel pebble leaving the core is located at the outlet. The central region of the conus is assumed as node 0 . The core diameter is $300 \mathrm{~cm}$ and core height is $943 \mathrm{~cm}[11]$.

3. The calculation is based on neutronic spectrum and power density as well as power peak factor. The maximum neutronic spectrum occurs at the center of HTGR core as high as $8.94861 \times 10^{13}$ $1 / \mathrm{cm}^{2}$.det.eV at neutronic energy about $4.25 \times 10^{-2} \mathrm{eV}$. The calculation of power density generated by the fuel in the HTGR core is $4.7186 \mathrm{Watt} / \mathrm{cm}^{3}$ and the generated power is $12.5810 \mathrm{MWt}$. The power density of HTGR core is $1.5973 \mathrm{Watts} / \mathrm{cm}^{3}$ and the generated power is $4.2590 \mathrm{MWt}$. The average axial power peak factor $\left(f_{Z}\right)$ is 1.321874 . The average radial power peak factor $\left(f_{R}\right)$ is 1.184757.

4. The observation node of the calculation at HTGR core done for each layer of TRISO, in radial direction for positions of $\mathrm{R}=0 \mathrm{~cm}$ (core center), $35 \mathrm{~cm}, 70 \mathrm{~cm}, 105 \mathrm{~cm}$ and $150 \mathrm{~cm}$. While for axial direction the observation carried out in such positions, i.e; $0 \mathrm{~cm}, 83.83 \mathrm{~cm}, 167.85 \mathrm{~cm}, 251.68 \mathrm{~cm}$, $335.51 \mathrm{~cm}, 419.33 \mathrm{~cm}, 503.36 \mathrm{~cm}, 587.19 \mathrm{~cm}, 671.02 \mathrm{~cm}, 754.84 \mathrm{~cm}, 838.87 \mathrm{~cm}, 922.7 \mathrm{~cm}$, and $943 \mathrm{~cm}$. In this calculation, core material is assumed as solid material. Material position in the core is assumed as a layer with particular radius.

5. The analysis is carried out based on the graphs generated from the calculation results and modeling by opening the simulation results using notepad and entering the data to Microsoft Excel and Sigma Plot. At the same time, simulation using VSOP'94 is performed by opening the Command Prompt in the computer under Windows 7 operating system. Then, the files in the VSOP' 94 application is opened through the Command Prompt by Run command and is followed by giving simulation result name and exported to a file with extension ".out". 


\section{RESULTS AND DISCUSSION}

This investigation consists of several steps, i.e. modelling, calculation, and result analysis. The modelling of TRISO and fuel pebble as well as HTGR200K core has been conducted, as outlined above.

\section{Solid Material in the Core}

HTGR utilizes solid material for moderator. One thing that should be concerned in designing solid material HTGR is the effect of damage of structural material mostly consisting of graphite. It is related to complex properties of graphite at high temperature, including changes of thermal properties such as thermal conductivities. Observation on solid material temperature in the reactor core is carried out at radial direction, starting from the center line of reactor core $(\mathrm{R}=0 \mathrm{~cm})$ to the wall of reactor pressure vessel $(\mathrm{R}=150 \mathrm{~cm})$. Meanwhile, to axial direction, observation is performed from inlet to outlet at position $\mathrm{Z}=0 \mathrm{~cm}$ until $\mathrm{Z}=943 \mathrm{~cm}$.

The temperature distribution at the upper zone of the core increases to the lower zone of the core. Heat transfer in the lower zone is different from that in the upper zone of the core due to different gravity load and elastic contact among fuel pebbles [11]. The results of the temperature distribution of solid material could not be obtained immediately as data selection should be carried out first. The data are then analyzed using Microsoft Excel and Sigma Plot to obtain the simulation results in form of chart, as shown in Figure 2. The results of solid material temperature distribution of this simulation indicate that the highest temperature in the core is $993.30^{\circ} \mathrm{C}$ at $(\mathrm{z}=419.3 \mathrm{~cm} ; \mathrm{r}=0 \mathrm{~cm})$ and the lowest temperature is $769^{\circ} \mathrm{C}$ at $(\mathrm{z}=0 ; \mathrm{r}=150 \mathrm{~cm})$.

The temperature of solid material in the core tends to decrease towards radial position, because the material gets farther away from the heat source and conduction heat transfer propagates radially. The figure shows that solid material temperature, which is as a function of position $(R, Z)$ decreases subsequently from the inner reflector, outer reflector, helium gas pipe channel, and reactor shielding. The temperature pattern of solid material follows heat generation produced by the fuel in the reactor core. Since material conductance in axial direction is constant and the temperature of helium gas flowing downward increases ( $Q$ gets higher), the temperature of solid material also gets higher.

The material located close to the fuel has the highest temperature, because an increase in temperature occurs in line with helium gas flow direction as a function of axial flow rate. The figure also indicates that temperature distribution of solid material is a function of position. The temperature of solid material in active core zone reaches its maximum at $999.3{ }^{\circ} \mathrm{C}$, which is located at radial position $\mathrm{R}=0 \mathrm{~cm}$ and $\mathrm{Z}=419.33 \mathrm{~cm}$.

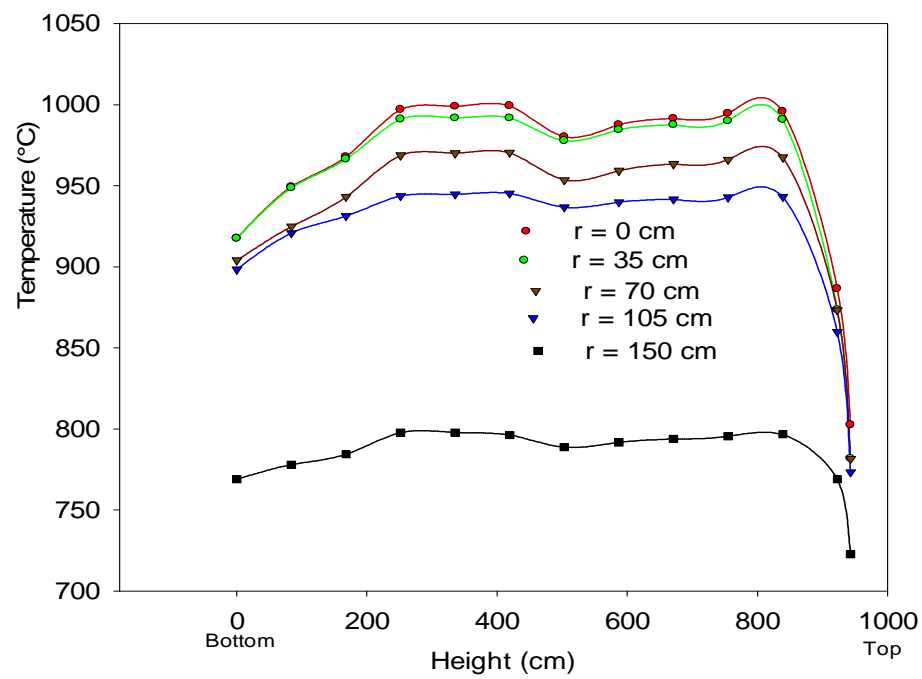

Figure 2. Temperature distribution of solid material towards core height direction 
The temperature of solid material tends to get lower as a function of position or in line with an increase in the core radius. At position at radius $\mathrm{R}=150 \mathrm{~cm}$, there is an apparent temperature difference compared with the temperature at other radius because of the presence of high coolant distribution at this position.

The temperature of solid material as a function of position ranges from $723{ }^{\circ} \mathrm{C}$ to $802.5^{\circ} \mathrm{C}$ and from $769^{\circ} \mathrm{C}$ to $917.6^{\circ} \mathrm{C}$ at the outlet. At the inlet of the gas to the core, the hottest temperature of solid material is $802.5{ }^{\circ} \mathrm{C}$, which increases axially to its maximum temperature at $999.3{ }^{\circ} \mathrm{C}$. The solid temperature at the outer pebble bed at height direction is a relation between the temperature and core height. The chart shows that the temperature depends on fuel's height and radial direction in the core.

\section{Fuel temperature in the core}

Fuel pebbles in the reactor core are in random position such that they optimally occupy available spaces. This fuel position generates heat transfer by conduction mode occurring at the contacted fuel surfaces. Meanwhile, helium gas flow at the inlet passes through the fuel wall and fills in the empty gaps in the inter-pebbles, and removes the generated heat by forced convection. In addition to conduction and convection modes, radiation heat transfer of the fuel pebble to its surrounding also occurs.

In the modeling to compute fuel pebble temperature, the reactor can be considered as fixed or packed bed reactor [11]. The design of packed bed reactor is based on mass and heat transfer mechanism and the decrease in fluid pressure and flow rate through fuel. Heat transfer of a unit of fuel pebble includes a complex three-dimensional geometry and consists of various material. Therefore, temperature calculation is based on a heat transfer model that is related to radiation, convection, and conduction. Heat transfer through fuel pebble occurs partly by thermal conduction in the pebble and partly by radiation from one to another pebble.

Heat transfer mechanism can be explained by defining the effective thermal conductivity. The fuel pebble temperature in the reactor core is a summation of conduction heat among the fuel pebbles, convection between fuel pebble surfaces, and radiation emitted by the fuel.The effective thermal conductivity of fuel pebble depends not only on fuel pebble material properties, but also on the flow and condition of heat transfer and particle shape. Effective thermal conductivity is assumed to have three parts, i.e. conduction through solid phase and radiation between pebbles, conduction through solid phase and all stationary fluid phases filling the interstitial cavity among pebbles, and conduction through solid phase and all pebble interfaces.

The observation on fuel temperature as a function of position $(\mathrm{R}, \mathrm{Z})$ to radial direction is carried out from $\mathrm{R}=0 \mathrm{~cm}$ (center line position) to $\mathrm{R}=150 \mathrm{~cm}$ (near the outer layer of annular core), while the position to axial direction is set from $R=0$ to $R=943 \mathrm{~cm}$. The fuel pebble of HTGR consists of a large number of TRISO fuel (in form of $\mathrm{UO}_{2}$ kernel coated by porous carbon buffer, C) inner pyrolytic carbon, IPyC), silicon carbide ( $\mathrm{SiC})$, and outer pyrolytic carbon, OPyC). The calculation of heat transfer in TRISO is performed by computing each layer's conductivity.

In accordance with the number of layers plus fuel kernel, the modeling of fuel pebble is divided into 5 radial zones. The results of the temperature distribution of fuel pebble could not be obtained immediately, but data selection should be carried out first. The data are then analyzed using Microsoft Excel and Sigma Plot to obtain the simulation results in form of chart, as shown in Fig. 2. The fuel temperature distributions as a function of position in the core are shown in Figure 3 until Figure 7. 


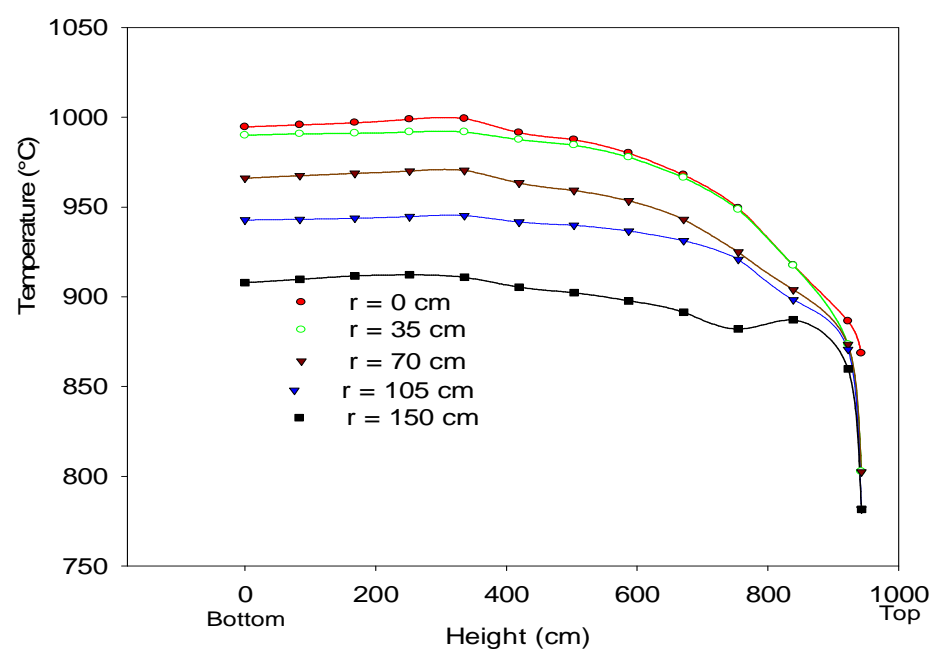

Figure 3. The result of OPyC temperature distribution towards core height direction

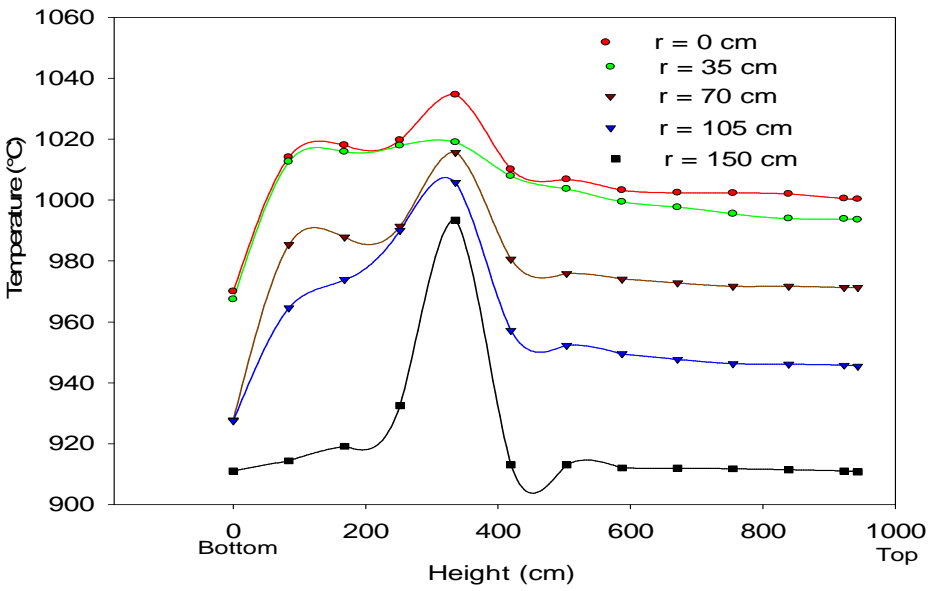

Figure 4. The result of $\mathrm{SiC}$ temperature distribution towards core height direction

The results of OPyC layer of this simulation indicate that the highest temperature is $993.30{ }^{\circ} \mathrm{C}$ at position $(\mathrm{z}=335.51 \mathrm{~cm} ; \mathrm{r}=0 \mathrm{~cm})$ and the lowest temperature is $781.6^{\circ} \mathrm{C}$ at position $(\mathrm{z}=943 \mathrm{~cm} ; \mathrm{r}=150$ $\mathrm{cm})$. Meanwhile, the highest temperature of $\mathrm{SiC}$ layer is $1034.6^{\circ} \mathrm{C}$ at $(\mathrm{z}=335.51 \mathrm{~cm} ; \mathrm{r}=0 \mathrm{~cm})$ and the lowest temperature is $910.80^{\circ} \mathrm{C}$ at $(\mathrm{z}=943 \mathrm{~cm} ; \mathrm{r}=150 \mathrm{~cm})$.

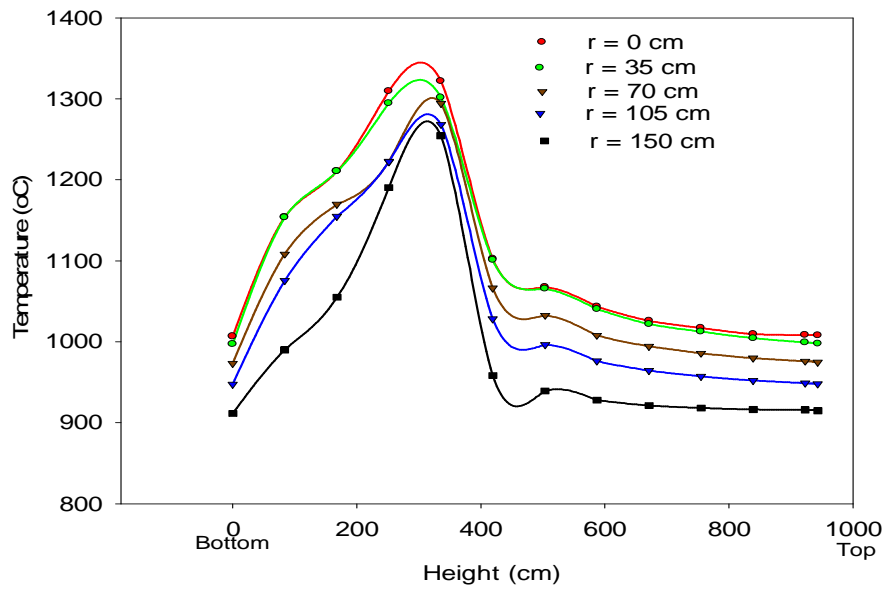

Figure 5.The result of IPyC temperature distribution towards core height direction 


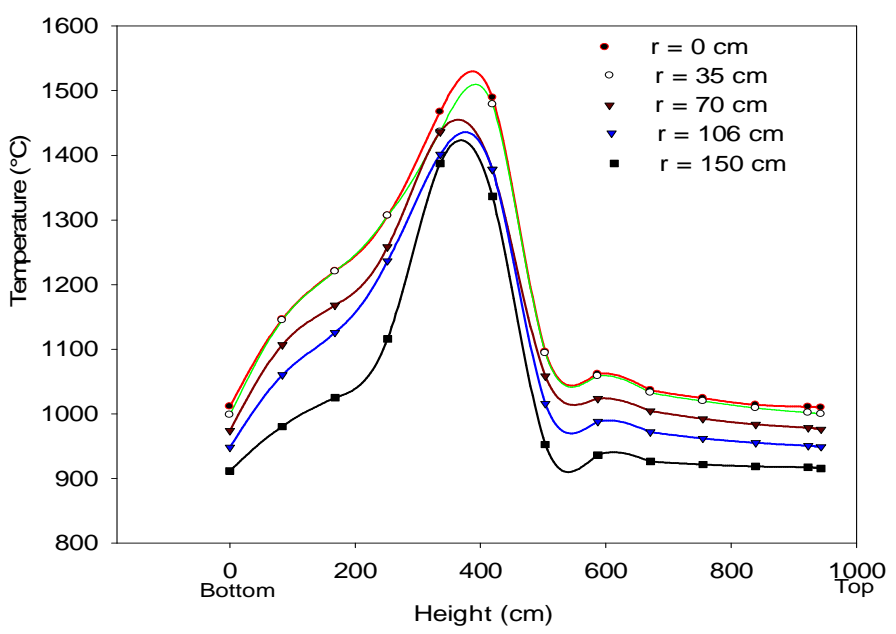

Figure 6. The result of buffer temperature distribution towards core height direction

The results of IPyC layer of this simulation indicate that the highest temperature of IPyC layer is 1322 ${ }^{\circ} \mathrm{C}$ at position $(\mathrm{z}=335.51 \mathrm{~cm} ; \mathrm{r}=0 \mathrm{~cm})$ and the lowest temperature is $911.40^{\circ} \mathrm{C}$ at $(\mathrm{z}=0 \mathrm{~cm} ; \mathrm{r}=150 \mathrm{~cm})$. Meanwhile, the buffer has the highest temperature of $1489.4{ }^{\circ} \mathrm{C}$ at position $(\mathrm{z}=419,33 \mathrm{~cm} ; \mathrm{r}=0 \mathrm{~cm})$ and the lowest temperature is $911.60{ }^{\circ} \mathrm{C}$ at $(\mathrm{z}=943 \mathrm{~cm} ; \mathrm{r}=0 \mathrm{~cm})$.

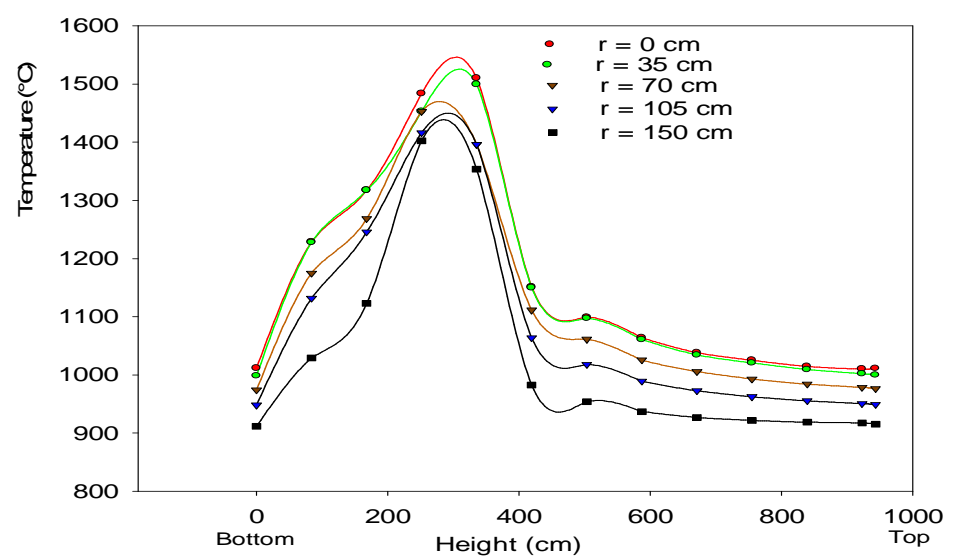

Figure 7. The result of kernel temperature distribution towards core height direction

The results of fuel kernel temperature distribution of this simulation indicate that the highest temperature of fuel kernel is $1510.3^{\circ} \mathrm{C}$ at position $(\mathrm{z}=335.51 \mathrm{~cm} ; \mathrm{r}=0 \mathrm{~cm})$ and the lowest temperature is $911.70{ }^{\circ} \mathrm{C}$ at position $(\mathrm{z}=0 \mathrm{~cm} ; \mathrm{r}=150 \mathrm{~cm})$. The calculation results of fuel temperature distribution indicate that the each TRISO layer has different temperature depending on its respective position in the core. The highest TRISO fuel temperatures are located at $\mathrm{R}=0 \mathrm{~cm}$ and $\mathrm{Z}=335.51 \mathrm{~cm}$, i.e. $1510.3{ }^{\circ} \mathrm{C}$, $1489.4{ }^{\circ} \mathrm{C}, 1322{ }^{\circ} \mathrm{C}, 1034.6{ }^{\circ} \mathrm{C}$ and $999.3{ }^{\circ} \mathrm{C}$, respectively from the fuel kernel to the outer layer, as shown in Figure 3 until Figure 7.

Fuel temperature tends to decrease as a function of position or in line with an increase in core diameter. At position with radius $\mathrm{R}=150 \mathrm{~cm}$, there is a significant difference between the fuel temperature at that position and the fuel temperature at other position. It is caused by the high coolant distribution at the related position. The temperature gradient from TRISO center to each layer is very stiff. It indicates that multiple layer confinement system of TRISO fuel works very well.

\section{Pressure Drop and Temperature Distribution of Helium Coolant}

The result of distribution of pressure drop of coolant fluid flow occurring at axial direction are shown in Table 3. Pressure drop profile at axial direction is observed at three locations, It shows that the pressure drop increases as a function of reactor core height. The calculation results indicate that the inlet pressure drop in the core central zone, average zone, and near wall zone ranges from 57.64725 $\mathrm{kPa}$ to $101.6473 \mathrm{kPa}$, while at that outlet of the same zone ranges from $750.1786 \mathrm{kPa}$ to $794.1786 \mathrm{kPa}$ 
under steady-state condition. The minimum pressure drop, respectively are at elevation of $943 \mathrm{~cm}$, i.e. $57.6473 \mathrm{kPa}, 62.41698 \mathrm{kPa}$ and $101.6473 \mathrm{kPa}$. The pressure drop in the core central zone, average zone, and near wall zone becomes maximum at elevation of $0 \mathrm{~cm}$ under steady-state condition. The maximum pressure drop, respectively are at elevation of $0 \mathrm{~cm}$, i.e. $750.1786 \mathrm{kPa}, 776.1786 \mathrm{kPa}$ and $794.1786 \mathrm{kPa}$.This process, pressure drop occurs due to friction with fuel pebbles. These pressure drop values are high enough from a view point of a pressure drop criterion for HTGR. This primary due to lower power density and larger density reactivity coefficient in the HTGR compared with those of a current HTR-module. Pressure drop in the pebble bed occurs because of friction between the gas coolant flow and the fuel pebbles, and between the gas coolant flow with core structure. Large pressure drop along pebble bed core can be caused by a leakage or bypass flow. Moreover, higher reactor core can cause higher pressure drop. Pressure drop along the pebble bed caused by friction is an important phenomenon that finally generates effective heat transfer. The cause of pressure drop is similar to turbo machine with proper size, which defines flow distribution through the main core structure, i.e. graphite block. Large pressure drop along the pebble bed caused by leakage or bypass flow through core structure will be minimized by the core design.

Table 3. Pressure drop at axial direction in the core

\begin{tabular}{llll}
$\begin{array}{l}\text { Axial direction } \\
\text { in the core } \\
(\mathrm{cm})\end{array}$ & $\begin{array}{l}\text { Pressure drop } \\
\text { in the core central zone } \\
(\mathrm{kPa})\end{array}$ & $\begin{array}{l}\text { Pressure drop } \\
\text { in the core average } \\
\text { zone }(\mathrm{kPa})\end{array}$ & $\begin{array}{l}\text { Pressure drop } \\
\text { In the near wall } \\
(\mathrm{kPa})\end{array}$ \\
\hline 0 & 750.1786 & 776.1786 & 794.1786 \\
35 & 749.3293 & 775.3293 & 793.3293 \\
91.7 & 748.4801 & 774.4801 & 792.4801 \\
145 & 730.6467 & 756.6467 & 774.6467 \\
241.7 & 690.7338 & 716.7338 & 734.7338 \\
283.5 & 644.4518 & 670.4518 & 688.4518 \\
366.9 & 592.2254 & 618.2254 & 636.2254 \\
450.4 & 534.9036 & 560.9036 & 578.9036 \\
533.8 & 473.7605 & 499.3359 & 517.7605 \\
617.3 & 409.6451 & 435.2205 & 453.6451 \\
669.1 & 343.4066 & 368.982 & 387.4066 \\
689.3 & 275.8944 & 301.4698 & 319.8944 \\
709.5 & 207.9575 & 232.2591 & 251.9575 \\
725 & 141.7191 & 160.9254 & 185.7191 \\
765 & 103.9292 & 112.9400 & 147.9292 \\
805 & 90.76647 & 98.50844 & 134.7665 \\
880 & 69.11159 & 83.22265 & 113.1116 \\
905 & 62.31791 & 75.57975 & 106.3179 \\
930 & 58.49646 & 67.93685 & 102.4965 \\
943 & 57.64725 & 62.41698 & 101.6473 \\
\hline
\end{tabular}

The result of pressure drop of coolant fluid flow accuring at radial direction in the core inlet zone, core center and outlet as shown in Table 4.

Pressure drop profile at radial direction is observed at three locations, respectively i.e. the inlet core side, middle core side, and outlet core. It shows that the pressure drop constant as a function of reactor core radial. The result of the pressure drop in the inlet core side, middle core side and outlet core side ranges from $101.6473 \mathrm{kPa}$ to $794.1786 \mathrm{kPa}$, while at that outlet of the same zone ranges from $794.1786 \mathrm{kPa}$ to $794.1786 \mathrm{kPa}$ under steady-state condition. The minimum pressure drop is at radial of $943 \mathrm{~cm}$ under inlet core side, i.e. $101.6473 \mathrm{kPa}$. The pressure drop in the inlet core side, middle core side, and outlet core side becomes maximum at elevation of $0 \mathrm{~cm}$ under steady-state condition. The maximum pressure drop is at radial of $0 \mathrm{~cm}$ under outlet core side, i.e. $794.1786 \mathrm{kPa}$. This is primary due to the helium gas is circulated to the inlet and then is directed to enter the core. Helium gas transfers heat in the fuel pebble gaps by forced convection. Helium coolant enters the reactor core from the top side and flows downward through gaps among fuel pebbles, transfers the heat generated by nuclear fission reaction, and leaves the core to IHX so that the heat can be used accordingly. Coolant 
fluid is helium gas flowing at flow rate of $120 \mathrm{~kg} / \mathrm{second}$ and inlet pressure of $7000 \mathrm{kPa}$ through the coolant channel from the core outlet.

Table 4. Coolant pressure drop at radial direction

\begin{tabular}{llll}
\hline $\begin{array}{c}\text { Radial direction } \\
\text { in the core }(\mathrm{cm})\end{array}$ & $\begin{array}{c}\text { Pressure drop } \\
\text { outlet core side }(\mathrm{kPa})\end{array}$ & $\begin{array}{c}\text { Pressure drop } \\
\text { middle core side }(\mathrm{kPa})\end{array}$ & $\begin{array}{c}\text { Pressure drop } \\
\text { inlet core side }(\mathrm{kPa})\end{array}$ \\
\hline 0 & 794.1786 & 387.4066 & 101.6473 \\
8.3 & 794.1786 & 387.4066 & 101.6473 \\
16.7 & 794.1786 & 387.4066 & 101.6473 \\
25 & 794.1786 & 387.4066 & 101.6473 \\
35 & 794.1786 & 387.4066 & 101.6473 \\
43.8 & 794.1786 & 387.4066 & 101.6473 \\
52.5 & 794.1786 & 387.4066 & 101.6473 \\
61.2 & 794.1786 & 387.4066 & 101.6473 \\
70 & 794.1786 & 387.4066 & 101.6473 \\
78.8 & 794.1786 & 387.4066 & 101.6473 \\
87.5 & 794.1786 & 387.4066 & 101.6473 \\
96.2 & 794.1786 & 387.4066 & 101.6473 \\
105 & 794.1786 & 387.4066 & 101.6473 \\
113.8 & 794.1786 & 387.4066 & 101.6473 \\
122.5 & 794.1786 & 387.4066 & 101.6473 \\
131.2 & 794.1786 & 387.4066 & 101.6473 \\
140 & 794.1786 & 387.4066 & 101.6473 \\
146 & 794.1786 & 387.4066 & 101.6473 \\
150 & 794.1786 & 387.4066 & 101.6473 \\
\hline
\end{tabular}

The calculation result of the coolant temperature distribution of as a function of core height in inlet zone, core center, and outlet zone as shown in Table 5.

Table 5. The calculation results of the coolant temperature distribution of as a function of core height

\begin{tabular}{lccccccccr}
\hline $\begin{array}{c}\text { Axial } \\
(\mathrm{cm})\end{array}$ & $\begin{array}{c}\mathrm{T} \\
\mathbf{0} \mathrm{cm}, \\
\left({ }^{\circ} \mathrm{C}\right)\end{array}$ & $\begin{array}{c}\mathrm{T} \\
17 \mathrm{~m} \\
\left({ }^{\circ} \mathrm{C}\right)\end{array}$ & $\begin{array}{c}35 \mathrm{~cm} \\
\left({ }^{\circ} \mathrm{C}\right)\end{array}$ & $\begin{array}{c}53 \mathrm{~cm} \\
\left({ }^{\circ} \mathrm{C}\right)\end{array}$ & $\begin{array}{c}\mathrm{T} \\
70 \mathrm{~cm} \\
\left({ }^{\circ} \mathrm{C}\right)\end{array}$ & $\begin{array}{c}\mathrm{T} \\
88 \mathrm{~cm} \\
\left({ }^{\circ} \mathrm{C}\right)\end{array}$ & $\begin{array}{c}\mathrm{T} \\
105 \mathrm{~cm} \\
\left({ }^{\circ} \mathrm{C}\right)\end{array}$ & $\begin{array}{c}\mathrm{T} \\
123 \mathrm{~cm} \\
\left({ }^{\circ} \mathrm{C}\right)\end{array}$ & $\begin{array}{c}\mathrm{T} \\
150 \mathrm{~cm} \\
\left({ }^{\circ} \mathrm{C}\right)\end{array}$ \\
\hline 943 & 755 & 755 & 755 & 752 & 747 & 742 & 776 & 784 & 776 \\
922.7 & 846 & 847 & 847 & 842 & 833 & 824 & 860 & 858 & 844 \\
838.9 & 891 & 891 & 890 & 884 & 872 & 862 & 877 & 862 & 841 \\
754.8 & 922 & 922 & 922 & 913 & 898 & 888 & 894 & 876 & 855 \\
671 & 941 & 941 & 939 & 930 & 916 & 905 & 904 & 885 & 864 \\
587.2 & 953 & 953 & 951 & 941 & 926 & 914 & 909 & 891 & 870 \\
503.4 & 960 & 960 & 957 & 947 & 932 & 921 & 912 & 894 & 875 \\
419.3 & 964 & 964 & 960 & 950 & 936 & 924 & 914 & 896 & 878 \\
335.5 & 967 & 966 & 963 & 953 & 939 & 927 & 915 & 898 & 880 \\
251.7 & 969 & 968 & 963 & 954 & 940 & 928 & 916 & 899 & 882 \\
167.9 & 970 & 969 & 964 & 954 & 941 & 929 & 916 & 900 & 884 \\
83.8 & 972 & 970 & 964 & 955 & 943 & 930 & 917 & 902 & 885 \\
0 & 972 & 970 & 964 & 955 & 943 & 931 & 918 & 902 & 883 \\
\hline
\end{tabular}

The calculation results indicate that the coolant temperatureat the center core ranges from 755 ${ }^{\circ} \mathrm{C}$ up to $972{ }^{\circ} \mathrm{C}$, while at the core average zone the coolant temperature is in the range of $747{ }^{\circ} \mathrm{C}$ up to $943{ }^{\circ} \mathrm{C}$ and the near wall the coolant temperature is in the range of $776{ }^{\circ} \mathrm{C}$ up to $883{ }^{\circ} \mathrm{C}$. It can be understood because there is a presence of heat generated by fission products transferred by both convection and radiation mechanism. Temperature distribution at the reactor center line is little higher than that of near wall since solid material in the near wall zone does not contribute any heat.

The calculation results indicate that the coolant temperature distribution with core height in inlet zone, core center, and outlet zone. The results are shown in Table 5 at the center zone ranges from 755 
${ }^{\circ} \mathrm{C}$ up to $972{ }^{\circ} \mathrm{C}$, while at the outlet the coolant temperature is in the range of $883{ }^{\circ} \mathrm{C}$ up to $972{ }^{\circ} \mathrm{C}$. It can be understood because there is a presence of heat generated by fission products transferred by both convection and radiation mechanism. Temperature distribution at the reactor center line is little higher than that of near wall since solid material in the near wall zone does not contribute any heat.

Helium gas coolant is injected to the cavity areas at temperature of $650{ }^{\circ} \mathrm{C}$. Helium gas temperature distribution after entering the core at the height of $943 \mathrm{~cm}$ of the upper side of reactor core is relatively the same. The temperature distribution results in the radial inlet zone, radial central zone, and radial outlet zone at radial direction of reactor core are $742{ }^{\circ} \mathrm{C}$ up to $776{ }^{\circ} \mathrm{C}, 875{ }^{\circ} \mathrm{C}$ up to $960{ }^{\circ} \mathrm{C}$, and $883^{\circ} \mathrm{C}$ up to $972{ }^{\circ} \mathrm{C}$, respectively. The temperature gradient of each zone is relatively small due to gas coolant turbulence among fuel pebbles causing coolant flow at the same height to be relatively homogeneous. Table 5 shows that the coolant temperature range at the inlet zone differs significantly from that of central zone and outlet zone because of the influence of power peak distribution.

The coolant temperature becomes maximum at the elevation of $0 \mathrm{~cm}$ and radial $0 \mathrm{~cm}$ under steady-state condition. The maximum coolant temperature is $972{ }^{\circ} \mathrm{C}$. These maximum coolant temperature values are high enough from a view point of a coolant temperature criterion for HTGRcogeneration purposes as to produce hydrogen gas.

\section{CONCLUSION}

The results of investigation on thermal-flow characteristics of HTGR carried out indicate the characteristics of the temperature distribution in the solid, each fuel layer, helium gas and pressure drop of HTGR200K core. Therefore, fuel pebble integrity and its cogeneration can be figured out in accordance with the UCD developed. At steady state condition, the investigation results show the reactor core's temperature distribution of 5-layer TRISO fuel pebble and outlet temperature of the reactor core. The highest and lowest temperatures in the reactor core are $999.3{ }^{\circ} \mathrm{C}$ and $886.5{ }^{\circ} \mathrm{C}$, while the highest temperature of TRISO $\mathrm{UO}_{2}$ is $1510.20^{\circ} \mathrm{C}$ in the position $(\mathrm{z}=335.51 \mathrm{~cm} ; \mathrm{r}=0 \mathrm{~cm})$.

Moreover, the temperatures resulted in this investigation are compared with that of the previous research and with the maximum safety margin of fuel pebble temperature, i.e. $1600{ }^{\circ} \mathrm{C}$. This value is chosen as a limit so that fuel pebble integrity is maintained and no radionuclide, such as Cs-137 causing hazard to human body, is released. Therefore, the HTGR core design meets the safety criteria. Moreover, investigation on thermal-flow characteristics of HTGR200K using THERMIX-KONVEK Module is very beneficial for considering the best and most suitable reactor type for BATAN.

\section{ACKNOWLEDGEMENT}

My appreciation is given to Drs. Putranto Ilham Yazid for running VSOP code. Many thanks are delivered to DR. M. Subekti and Ir. Suwoto for their fruitful discussion as well as to DR. Mulya Juarsa as the KPTF members for his willingness to review this paper.

\section{REFERENCES}

1. Reitsma F., Naidoo D., Evaluating the control rod modelling approach used inthe South African PBMR: comparison of VSOP calculations with ASTRA experiments, Nuclear Engineering and Design. 2010;222:147-159.

2. Pilehvar A.F., Aghaie M., Esteki M.H., Zolfaghari A., Minuchehr A., Daryabak A., Safavi A., Evaluation of compressible flow in spherical fueled reactors using the porous media model, Annals of Nuclear Energy. 2013;57:185-194

3. Javier Ortensi, Brian Boer, Abderrafi M. Ougouag, THETRIS: A micro-scale temperature and gas release model for TRISO fuel, Nuclear Engineering and Design. 2011;241:5018-5032

4. XiankeMeng, Zhongning Sun, GuangzhanXu, Single-phase convection heat transfer characteristics of pebble-bed channels with internal heat generation, Nuclear 
Engineering and Design. 2012;252:121- 127

5. Espinosa-Paredes G., Castillo-Jiménez V., Herranz-Puebla L.E., Vázquez-Rodríguez R., Analysis of the interfacial heat transfer process in a pebble fuel, Progress in Nuclear Energy 65 (2013) 15-31

6. Van Antwerpen W., P.G. Rousseau, C.G. du Toit, Multi-sphere Unit Cell model to calculate the effective thermal conductivity in packed pebble beds of mono-sized spheres, Nuclear Engineering and Design. 2012;247:183- 201

7. S. Yamoah, E.H.K. Akaho, Nana G.A. Ayensu and M. Asamoah, Analysis of Fluid Flow and Heat Transfer Model for the Pebble Bed HighTemperature Gas Cooled Reactor, Research Journal of Applied Sciences, Engineering and Technology 4(12); 2012:1659-1666

8. Yanhua Zheng, Lapins, E. Laurien, L. Shia, Z. Zhang, Thermal hydraulic analysis of a pebble-bed modular high temperature gas-cooled reactor with ATTICA3D and THERMIX codes, Nuclear Engineering and Design 246 (2012) 286- 297.

9. Mohammad Dhandhang Purwadi, Analisis dan Optimasi Desain Sistem Reaktor Gas Temperatur Tinggi RGTT200K dan RGTTT200KT, Jurnal Teknologi Reaktor Nuklir Tri Dasa Mega, Vol.14 No.1, (2012) 1-13

10. Teuchert E., Haas K.A., Rütten H.J., Brockmann H., Gerwin H., Ohlig U., Scherer W. V.S.O.P. (94): Computer Code System for Reactor Physics and Fuel Cycle Simulation. Forschungszentrum Jülich, Jül-2897, (April 1994)

11. Sudarmono, Analisis perpindahan panas solid material RGTT200K. Jurnal Teknologi Bahan Nuklir. 2014;10:15-22

12. Mohammad Dhandhang Purwadi,Analisis Termal-Aliran Kisi Bahan Bakar Bola Teras RGTT200K dengan FLUENT Jurnal Teknologi Reaktor Nuklir Tri Dasa Mega, Vol.14 No.3, (2012), 146-156

13. IAEA-TECDOC-CD-1674, "Advances in high temperature gas cooled reactor fuel technology", Vienna : International Atomic Energy Agency, Dec. 2012.

14. Sudarmono, Suwoto, Hery Adrial, Sensitivitas Pengayaan Uranium dan Fraksi Packing (3Th,U) $\mathrm{O}_{2}$ Terhadap $\mathrm{K}_{\infty}$ Sebagai Dasar Desain Konseptual RGTT200K. Jurnal Ilmiah Daur Bahan Bakar Nuklir. 2013; 19; 25-38 